\title{
Cataloging of Cd Allocation in Late Rice Cultivars Grown in Polluted Gleysol: Implications for Selection of Cultivars with Minimal Risk to Human Health
}

\author{
Qiang Lin ${ }^{1,+}$, Wenbin Tong ${ }^{2, *,+}$, Bilal Hussain ${ }^{1,+}$, Yasir Hamid ${ }^{1} \oplus$, Min Lu ${ }^{1}$, Zhenli He ${ }^{3 \oplus}$ and \\ Xiaoe Yang ${ }^{1, *}$ \\ 1 Ministry of Education (MOE) Key Laboratory of Environmental Remediation and Ecosystem Health, \\ College of Environmental and Resources Science, Zhejiang University, Hangzhou 310058, China; \\ linqdeyx@163.com (Q.L.); bilalcheema74@gmail.com (B.H.); yasirses2007@gmail.com (Y.H.); \\ lumin_1994@163.com (M.L.) \\ 2 Technical Extension Station of Soil Fertilizer and Rural Energy, Qujiang, Quzhou 324022, China \\ 3 Indian River Research and Education Center, Institute of Food and Agricultural Sciences, \\ University of Florida, Fort Pierce, FL 34945, USA; zhe@ufl.edu \\ * Correspondence: zjqztwb@163.com (W.T.); xeyang@zju.edu.cn (X.Y.); Tel.: +86-13858085377 (X.Y.); \\ Fax: +86-571-88982907 14 (X.Y.) \\ + Authors contribute equally.
}

Received: 7 April 2020; Accepted: 15 May 2020; Published: 21 May 2020

\begin{abstract}
Cadmium (Cd) is a toxic trace metal that has polluted $20 \%$ of agricultural land in China where its concentration exceeds the standards for Chinese farmland. Plants are capable of accumulating $\mathrm{Cd}$ and other trace metals, but this capacity varies with species and cultivars within a species. Rice is a staple food consumed by half of the global population. In order to select safe late rice cultivars that are suitable late rice cultivars that can be cultivated in for growing in slightly contaminated soil, a two-year field experiment was conducted with 27 in the first year and 9 late rice cultivars in the second year. The results showed that plant $\mathrm{Cd}$ concentrations varied among the cultivars, with high magnitudes of variation occurred in straw and grains. Five genotypes including LR-12, LR-17, LR-24, LR-25 and LR-26 were identified as low accumulators for the first year while LR-15 and LR-17 were identified as promising cultivars based on $\mathrm{Cd}$ concentration in the polished rice grains $\left(<0.02 \mathrm{mg} \mathrm{kg}^{-1} \mathrm{DW}\right)$. In addition, these cultivars had favorable traits, including mineral nutrition and grain yield. Therefore, these genotypes should be considered for cultivation in slightly or moderately Cd contaminated soils.
\end{abstract}

Keywords: cadmium; accumulation; genotypic; translocation; contaminated soil

\section{Introduction}

Rapid industrialization and hazard dumping of disposal wastes have enhanced the contamination of potential toxic metals (PTMs) to soils, causing public concerns about crop production, food safety and human health [1-3]. Among the PTMs, cadmium (Cd) is highly toxic and results in widespread pollution due to its extensive distribution and mobility in the environment $[4,5]$. As it is non-biodegradable, $\mathrm{Cd}$ can persist in soil for a long time [6]. According to the latest survey, Cd ranks first with 7\% contamination nationwide in China and is the most commonly detected trace metal in soils [3] of the investigated sites. Both natural processes $[7,8]$ and anthropogenic inputs contribute to PTM contamination to agricultural lands of China [3,9]. Meanwhile, uptake and accumulation of PTMs in crop plants and agricultural products affect directly the quality and productivity of crops and indirectly the human health via food chains [10]. 
Among all the PTMs, Cd is associated with severe health risks to organisms [11] as its intake can cause various disorders in human body (i.e., hypertension, cardiac failure, cancer, serious damage in lungs, in eyes, renal dysfunction and osteoporosis) [12]. In Asian countries, rice is considered as the major source for Cd toxicity in humans [3]. High Cd concentrations in rice grain $\left(>0.2 \mathrm{mg} \mathrm{kg}^{-1}\right)$ in China are mainly attributed to the local anthropogenic activities [13]. Metal intake and exposure at toxic levels occur in humans through food consumption of crops (wheat, rice, maize or derived products) grown on contaminated soils [7] and long-term consumption of contaminated food and water even at relatively low concentrations could lead to chronic diseases, including cancer $[7,8]$.

An elevated world population has led to increased food requirement, which is not possible to achieve without using all the available sources. Several remedies are reported in the literature to cope with metal contamination, including soil washing, phytoremediation, electro-kinetics, soil flushing and vitrification [14]. However, these practices are deployed with some pros and cons, especially time and costs, which limit their application at a large scale. Moreover, the soils with slight or moderate contamination have too large an area to be interrupted for remediation without agricultural activities [6]. To meet the basic food requirements it is imperative to find alternative ways to reduce metal transfer from soil to crops grown on slightly and moderately contaminated soils. It is necessary to identify crop cultivars with low accumulative capacity for PTMs and adequate yield. This approach may provide a long term solution to the management of contaminated soil.

Genetic variability includes the difference in uptake, translocation and accumulation of PTMs among the cultivars within the same species [15]. The variation among different crops and species for PTMs uptake and accumulation have been documented in maize [16,17], wheat [18], vegetables [19], Chinese cabbage (Brassica pekinensis L.) [20], water spinach (Ipomoea aquatica Forsk.) [21] and soybeans [22]. However, minimal information is available regarding the screening of late rice to achieve minimum $\mathrm{Cd}$ accumulation in edible parts (polished rice) and to maximize accumulation in straw, which can remove (phytoremediation).

Rice is an important staple food crop in Asian countries, especially in China. Rice plants can absorb and accumulate more PTMs, as compared to the other crops [23]. The variations in trace metal uptake, translocation and accumulation in edible parts of late rice cultivars were poorly understood. This two-year field experiment was designed to investigate metals accumulation of 27 late rice cultivars widely grown in Zhejiang, China in the 1st year and prescreened 9 cultivars in the 2nd year. The overall objective of this study was to select high yield late rice cultivars with least $\mathrm{Cd}$ accumulation in edible parts (polished rice) but maximum $\mathrm{Cd}$ accumulation in straw in order to meet the requirement of producing safe food on lightly and moderately contaminated soils.

\section{Materials and Methods}

\subsection{Experimental Site and Characterization}

A two-year field trial was conducted in the east of Zhejiang province, China (Latitude $28^{\circ} 56^{\prime} 52^{\prime \prime} \mathrm{N}$ and longitude $118^{\circ} 56^{\prime} 30^{\prime \prime} \mathrm{E}$ ) where is dominated by a subtropical monsoon climate with $18.6,18.2^{\circ} \mathrm{C}$ mean annual temperature, mean annual rainfall of 1308 and $1481 \mathrm{~mm}$ and sunshine of 1735 and $1748 \mathrm{~h}$, respectively in the 1st and 2nd year [24]. The geographical and meteorological map of the experimental site is presented in Figure 1. 

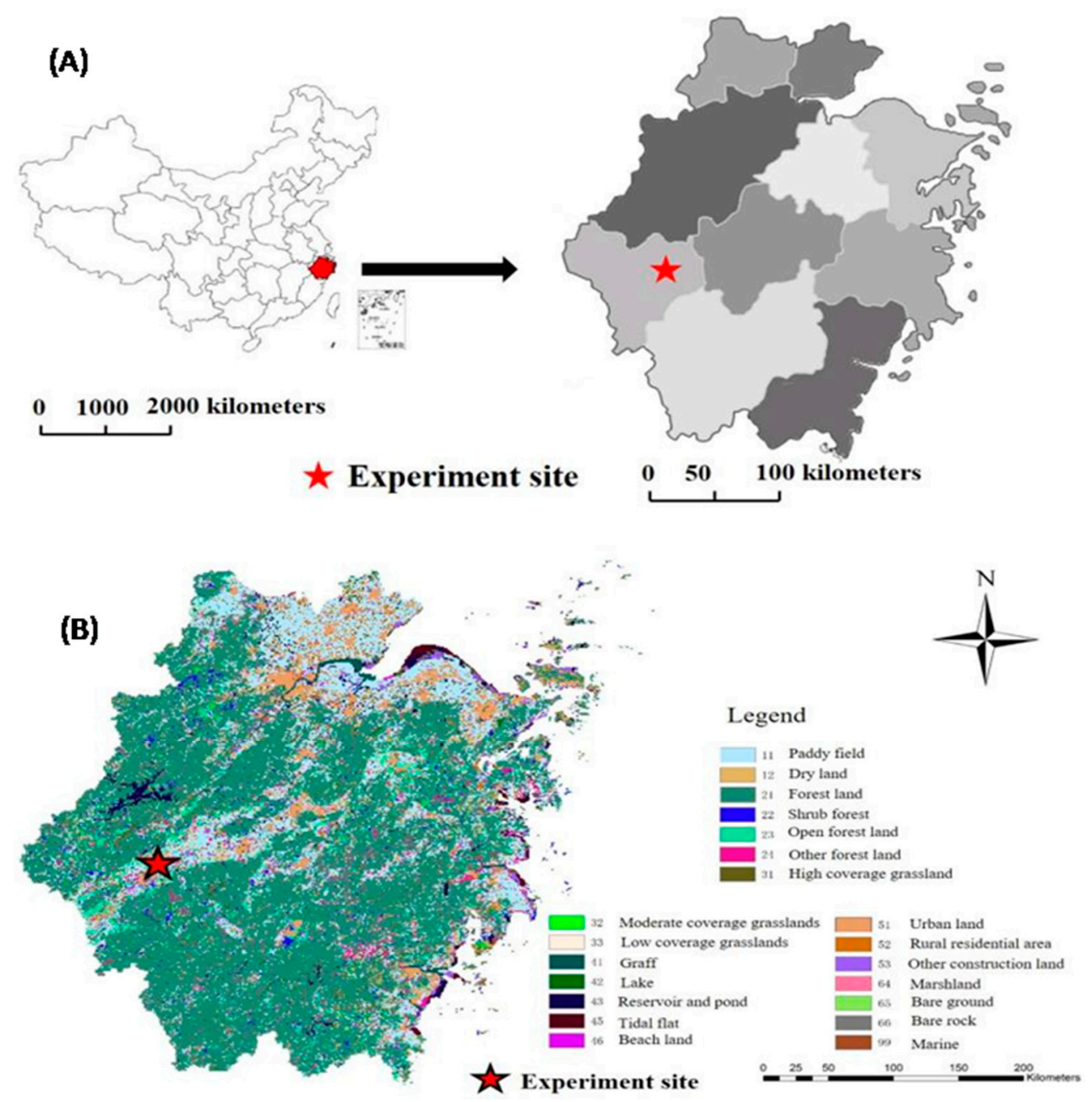

Figure 1. Geographical (A) and meteorological map (B) of the experimental site.

The soil was Cd contaminated mainly due to the parent materials [8], with a lower Cd concentration in the surface than that the middle and bottom layer. In addition, non-point source pollution might also contribute to the amount of soil Cd. It was estimated that inputs of atmospheric deposition, irrigation, straw return and fertilization amounted to 3.15, 4.35, 4.5 and $0.75 \mathrm{~g} /$ ha per year, respectively [24]. Prior to the start of experiment, basic soil physiochemical properties were analyzed $[25,26]$ and presented in Table 1.

Table 1. Basic physio-chemical properties of the soil used for the experiment.

\begin{tabular}{cc}
\hline Properties & Values \\
\hline Soil type & Red earth \\
$\mathrm{pH}$ & $5.83 \pm 0.04$ \\
Organic matter $(\%)$ & $7.25 \pm 0.03$ \\
Total N $\left(\mathrm{g} \mathrm{kg}^{-1}\right)$ & $2.10 \pm 0.03$ \\
Available $\mathrm{P}\left(\mathrm{mg} \mathrm{kg}^{-1}\right)$ & $53.9 \pm 4.69$ \\
Available K $\left(\mathrm{mg} \mathrm{kg}^{-1}\right)$ & $120 \pm 9.8$ \\
Total Cd $\left(\mathrm{mg} \mathrm{kg}^{-1}\right)$ & $0.85 \pm 0.06$ \\
Available Cd $\left(\mathrm{mg} \mathrm{kg}^{-1}\right)$ & $0.34 \pm 0.02$ \\
\hline
\end{tabular}

\subsection{Plant Material and Sample Collection}

Seeds of 27 late rice cultivars were purchased from the Quzhou seed market (Table S1). The seeds were surface sterilized, germinated and nursery-cultured in early July. The seedlings of 28 days 
old from the nursery were transplanted to field. The plot area was $22 \mathrm{~m}^{2}(2 \mathrm{~m} \times 11 \mathrm{~m})$ and each cultivar had three random replications following the complete randomized block design (RCBD). Fertilizer application $\left(\mathrm{N}-\mathrm{P}_{2} \mathrm{O}_{5}-\mathrm{K}_{2} \mathrm{O}: 145-60-165 \mathrm{kgha}^{-1}\right)$ and agronomic practices were the same for all the blocks. For the second-year experiment, 9 prescreened cultivars from the first year experiment based on metal accumulation were selected as high, medium and low accumulator to verify the selection. Six plants were harvested at the maturity stage and yield attributes were measured from $1 \mathrm{~m}^{2}$ /plot. Plant samples were rinsed with running deionization water, while roots, above-ground tissues and grains were separated and washed carefully with deionization water. The roots were first soaked in $20 \mathrm{mM}$ EDTA-2 Na for $15 \mathrm{~min}$ and then rinsed thoroughly with DI water. All the plant samples were oven-dried at $65^{\circ} \mathrm{C}$ until constant weights were achieved, while the rice grains were air dried.

\subsection{Soil and Plant Samples Analysis}

Soil samples at the depth of $0-20 \mathrm{~cm}$ were collected prior to transplanting and immediately after harvesting. All the samples were air dried, ground and sieved through a 1-mm sieve for basic chemical analysis. Total $\mathrm{Cd}$ concentration was determined by digesting $0.2 \mathrm{~g}$ soil with $\mathrm{HNO}_{3}: \mathrm{HClO}_{4}$ : $\mathrm{HF}$ $(5: 1: 1 \mathrm{v} / \mathrm{v} / \mathrm{v})$ and the supernatant was made up to volume with DI water and subjected to Inductively Coupled Plasma Massspectrometry (ICP-MS) analysis for metals concentration [11]. The plant samples (roots, shoots and grains) were weighed $(0.2 \mathrm{~g})$ and digested with $\left(\mathrm{HNO}_{3}: \mathrm{H}_{2} \mathrm{O}_{2}: 5: 1 \mathrm{v} / \mathrm{v}\right)$, the digested solution was diluted up to mark $(25 \mathrm{~mL})$ upon cooling and the concentration of $\mathrm{Cd}$ and the other elements were determined using ICP-MS (Agilent 7500a, USA, Thermo Fisher Scientific 7400, USA). To assure the quality of trace element analysis, blank and standard sample of soil (GSS-5) and plant (GBW (E) 080684) were prepared and analyzed.

Phytic acid contents were analyzed following the protocol of Dai [27]. The detailed procedure of phytic acid and protein content can be found elsewhere [3].

\subsection{Translocation and Bioaccumulation Factor}

Translocation factor (TF) was calculated the following formula to evaluate the capability of late rice cultivars in translocating $\mathrm{Cd}$ from root to the shoot and from shoot to grains.

$$
\begin{aligned}
\text { Translocation }_{\text {factor }} \text { f }_{-S}(\mathrm{TF}) & =\frac{C d \text { conc. in shoot }}{\mathrm{Cd} \text { conc. in root }} \\
\text { Translocation factor }_{S-G}(\mathrm{TF}) & =\frac{C d \text { conc. in grains }}{\mathrm{Cd} \text { conc. in shoot }}
\end{aligned}
$$

where (R-S) represents root to shoot ratio of Cd concentration while (S-G) represents shoot to grains ratio of $\mathrm{Cd}$ concentration on the DW basis.

Cadmium bioaccumulation factor was calculated by the ratio of $\mathrm{Cd}$ concentration in the polished rice to that in the soil.

\subsection{Statistical Analysis}

Statistical and hierarchical cluster were performed using the SPSS 20.0 (IBM, Armonk, NY, USA) and figures were prepared using Origin pro 8.5 (OriginLab Corporation, Northampton, MA, USA). All the presented data are means of three replicates \pm standard error. The difference in $\mathrm{Cd}$ concentration among the genotypes was analyzed using one-way ANOVA at $p<0.05$. The classification groups of cultivars were divided by different Euclidean distances; lesser Euclidean distances mean more similar individuals. 


\section{Results and Discussion}

\subsection{Plant Biomass and Grains Yield of Rice Cultivars}

Despite genetic variability, all the rice cultivars showed normal growth without any visual symptoms of $\mathrm{Cd}$ toxicity. However, there were considerable differences in plant biomass and grain yield (Figure 2).

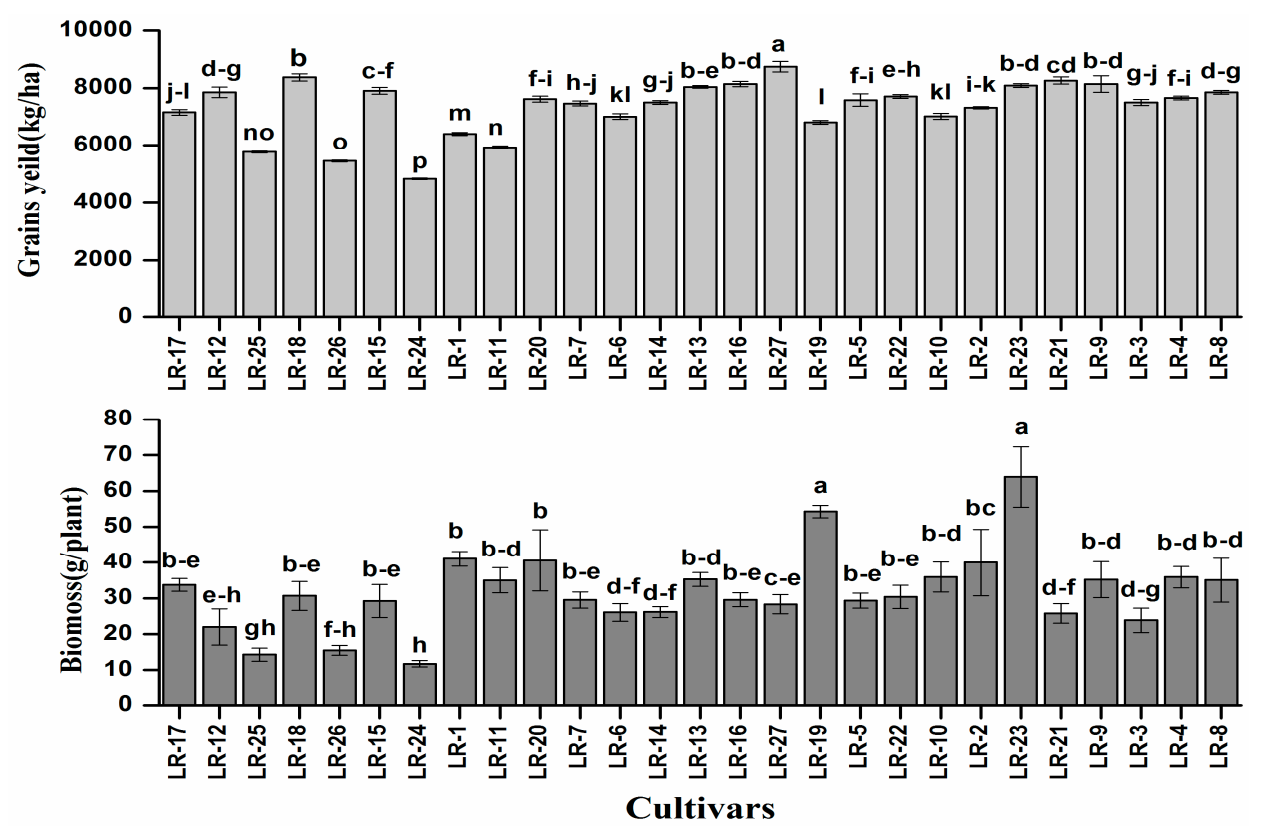

Figure 2. Grain yield and biomass of 27 late rice genotypes grown on Cd contaminated soil. Presented data are means of three replicates, error bars represent standard error. Different letters at the top of bars represent significant difference among the cultivars at $p<0.05$.

Plant biomass of all the genotypes varied from 12.5 (LR-24) to $65.4 \mathrm{~g}$ (LR-23), with the average value of $31.3 \mathrm{~g}$ and a 5.23-fold difference between the highest and the lowest biomass yield. The highest grain yield was recorded at $8741 \mathrm{~kg} / \mathrm{ha}$ (LR-27), which is 1.81-fold higher than the lowest yield of $4825 \mathrm{~kg} / \mathrm{ha}$ (LR-24). The considerable difference among the cultivars is analogous with the results reported for maize [28,29]. The variation among the cultivars in terms of plant biomass and grain yield might be attributed to the light interception, a key factor for the production of plant biomass via photosynthesis $[10,30]$. It is reported that metal tolerance of the plants can be estimated by growing the varieties with high tolerance capability on the slightly to moderately contaminated soil, while tolerance is evaluated by plant biomass and grain yield [20]. The relationship between different traits or cultivars is the main feature that assists for the selection in the breeding program of rice and other crops [31,32].

\subsection{Cadmium Concentration in Plant Tissues}

Cultivars differed remarkably in Cd concentration of polished rice (Figure 3).

The distribution of $\mathrm{Cd}$ in different parts of plant varied among the cultivars and generally decreased in the order of root $>$ shoot $>$ husk $>$ polished rice. The lowest $\mathrm{Cd}$ concentration in polished rice grains was $0.17 \mathrm{mg} \mathrm{kg}^{-1}$ occurred in LR-17 while the highest Cd concentration was $0.66 \mathrm{mg} \mathrm{kg}^{-1}$ measured in LR-8. The average Cd concentration in rice grain for the 27 genotypes was $0.37 \mathrm{mg} \mathrm{kg}^{-1}$, with a 3.47-fold difference between the highest and the lowest genotype. Only five cultivars, i.e., LR-17, LR-12, LR-25, LR-18 and LR-15 had a grain Cd concentration below the maximum permissible concentration in China (MPCC, $0.2 \mathrm{mg} \mathrm{kg}^{-1}$ ), and were considered suitable for safe production on the slightly or moderately contaminated soils. While, $\mathrm{Cd}$ concentration in rice straw ranged from 22.3 (LR-24) and $179.5 \mu$ plant $^{-1}$ (LR-9), with 8.05-fold difference between the highest and lowest 
accumulative cultivar. The concentration of $\mathrm{Cd}$ in straw is very important for the selection of cultivars not only for safe production but also for phytoremediation of contaminated soils [33]. The results from the second-year experiment revealed that the selected low accumulator (LR-12, LR-15 and LR-17) had grain Cd concentrations below the MPCC critical level for safe production (Table 2).

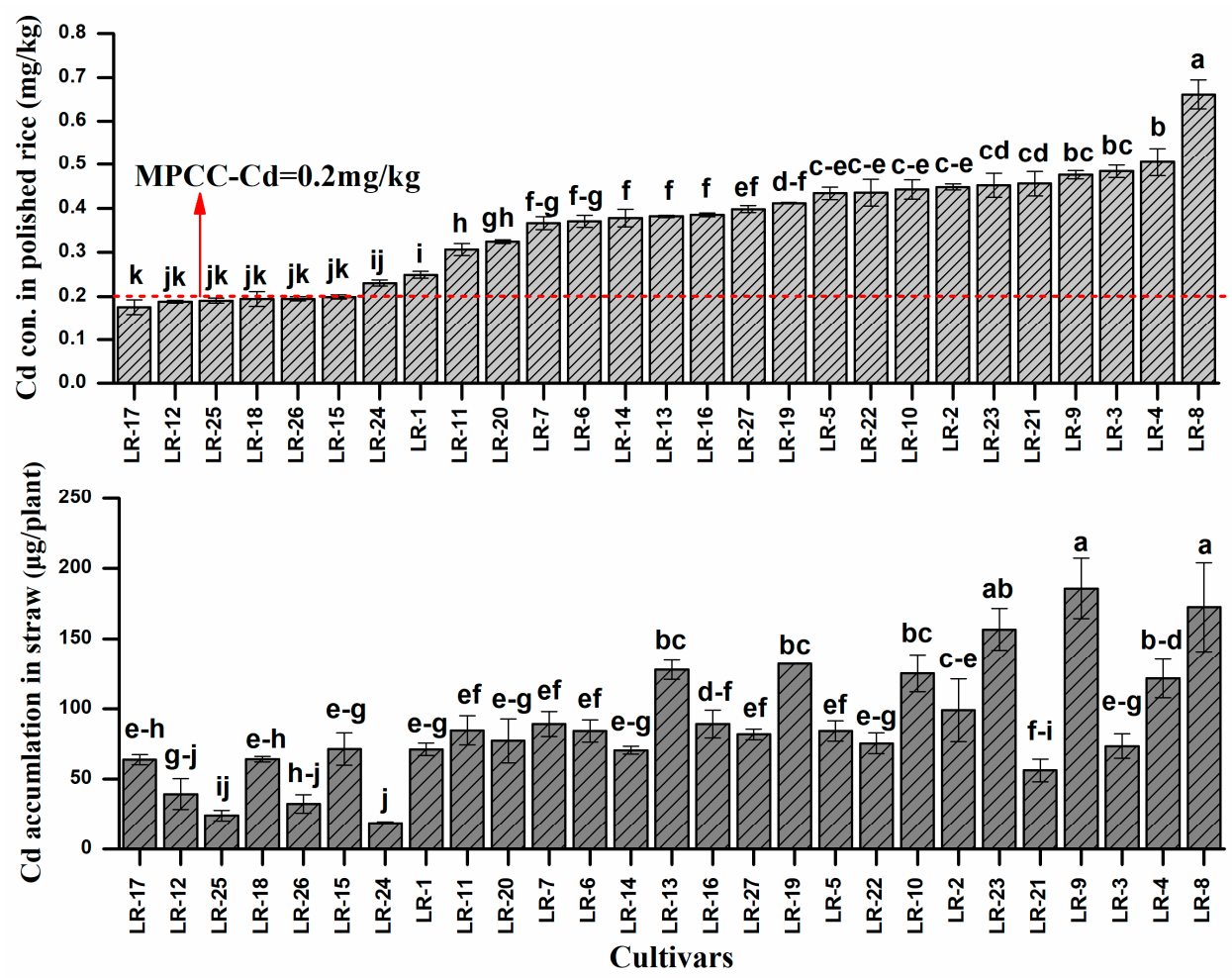

Figure 3. Cadmium concentration in polished rice grain and accumulation in straw of 27 late rice genotypes grown on Cd contaminated soil. Presented data are means of three replicates: error bars represent standard error. Different letters at the top of bars represent significant difference at $p<0.05$. MPCC denotes Maximum permissible concentration in China.

These results indicated the variation in plant biomass and $\mathrm{Cd}$ concentration among the different cultivars, with noticeable variation of $\mathrm{Cd}$ concentration in straw and polished rice grains of the same cultivars. The distribution ratio of $\mathrm{Cd}$ in the aboveground parts of the plant plays a major role in the variation of grain metal concentration. So, the difference in the grain metal concentration of the different cultivars may arise from the variation of total metal uptake. Previous studies have reported a positive correlation between grain and root concentration of metals [34,35]. Plant activities and characteristics, e.g., root surface area, mycorrhization and transpiration rate affects the metal availability in soil and subsequent accumulation in plants [36]. It was stated that, different plant species and cultivars show different trends in root activities, which ultimately affects metal availability in soil [37]. Lately, Zeng [38] also reported the consistent results that $\mathrm{Cd}$ concentration differs by 9.1 fold among the rice cultivars. The variance in $\mathrm{Cd}$ uptake and accumulation in different cultivars may be associated with root oxidation ability [39]. Previous experiments have revealed the behavioral variations of species in metal uptake and accumulation. These results reported the distribution of metals in various parts of plants, including roots and the aboveground parts [40,41].

\subsection{Variation in Accumulation, Translocation and Bioaccumulation of $C d$ among the Rice Cultivars}

All the rice genotypes showed variation in the accumulation and translocation of metals (Figure 4). The accumulation of trace metals in roots of rice cultivars differed greatly, with smaller variations occurring in shoots and grains. Overall, $\mathrm{Cd}$ accumulation in different parts of rice plants followed the trend of roots $>$ straw $>$ polished grains. Total $\mathrm{Cd}$ accumulation in the whole rice plant ranged from 
5.54 (LR-17) to $14.18 \mathrm{mg} \mathrm{kg}^{-1}$ (LR-9). The translocation factor (TF) was used to estimate the ability of plants to translocate metals to various parts. The $\mathrm{TF}_{\mathrm{RS}}$ and $\mathrm{TF}_{\mathrm{SG}}$ represents root to shoot and shoot to grains respectively and is presented in Figure 4. The maximum $\mathrm{TF}_{\mathrm{RS}}$ occurred in species LR-5 (66.23\%) while LR-17 had the lowest translocation (34.79\%). Meanwhile, TF SG $_{\text {was lowe }}$ in cultivar LR-16, which ranged from $9.43 \%$ (LR-16) to $22.31 \%$ (LR-21), implying a large variation among the late rice genotypes in the ability of translocating $\mathrm{Cd}$ from shoot to grain. Metal translocation is an important factor in controlling metals accumulation in edible parts of plants. Previous studies reported that most of the accumulated $\mathrm{Cd}$ in rice grains was transported via phloem [42,43]. Plant species grown on Cd contaminated soil differs in bioconcentration and translocation [44]. The differences among the rice cultivars in $\mathrm{Cd}$ uptake may be related to the characteristics of root absorption and exudate release. The translocation difference might also be attributed to the existing forms of $\mathrm{Cd}$ in soil solution. However, the mechanisms that control the translocation of $\mathrm{Cd}$ need further studies.

The bioaccumulation factor of $\mathrm{Cd}$ was lower than 1 for all the late rice cultivars with the minimum (0.2) in LR-17 and maximum bioaccumulation (0.8) in LR-8 (Figure 4). Our results showed that five cultivars had grain Cd below the MPCC $\left(0.2 \mathrm{mg} \mathrm{kg}^{-1}\right)$, indicating that these cultivars accumulated the least $\mathrm{Cd}$ in polished rice and hence were suitable for cultivation on the contaminated soil.

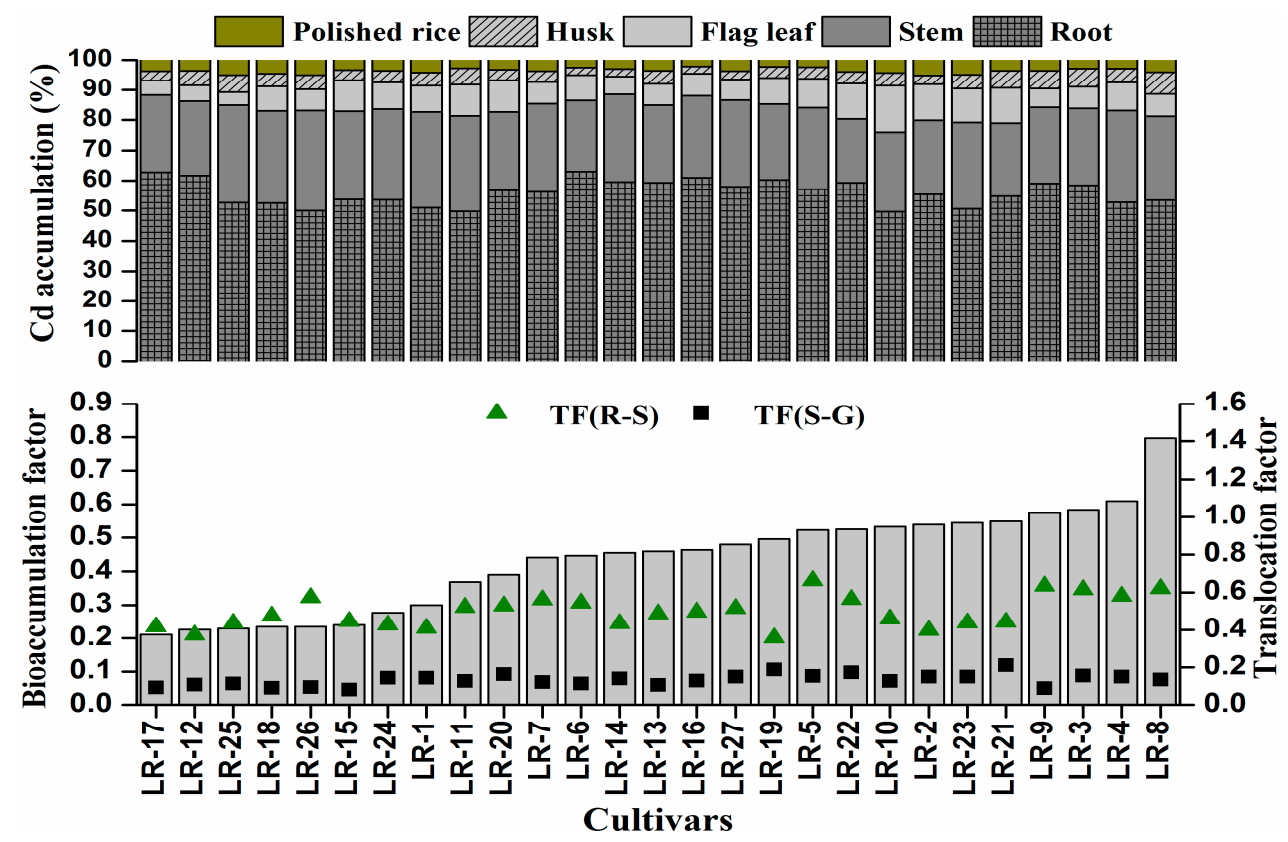

Figure 4. Cadmium accumulation in different parts of plant, bioaccumulation factor in polished rice grain and translocation factor of 27 late rice genotypes grown on contaminated soil. Where TF(R-S) and TF (S-G) represents root to shoot and shoot to grain translocation, respectively.

\subsection{Correlation between Cd Concentration in Polished Rice and Cd Concentration in Other Parts of Plants}

There were good correlations between the $\mathrm{Cd}$ concentration in polished rice and that in root, straw or flag leaf (Figure 5).

The correlation coefficients $\left(\mathrm{r}^{2}\right)$ were $0.655,0.758$ and 0.566 , respectively. Whereas correlation was negative between straw $C d$ and $Z n$ concentration in polished rice $\left(R^{2}=-0.532\right)$. Previous reports showed that $\mathrm{Zn}$ concentration was negatively correlated with other trace metals in rice plants [3]. Our results suggested that there is an antagonism effect between $\mathrm{Zn}$ and $\mathrm{Cd}$ accumulation in polished rice, and thus application of $\mathrm{Zn}$ may reduce the accumulation of $\mathrm{Cd}$ in rice grains for production of safe food. 

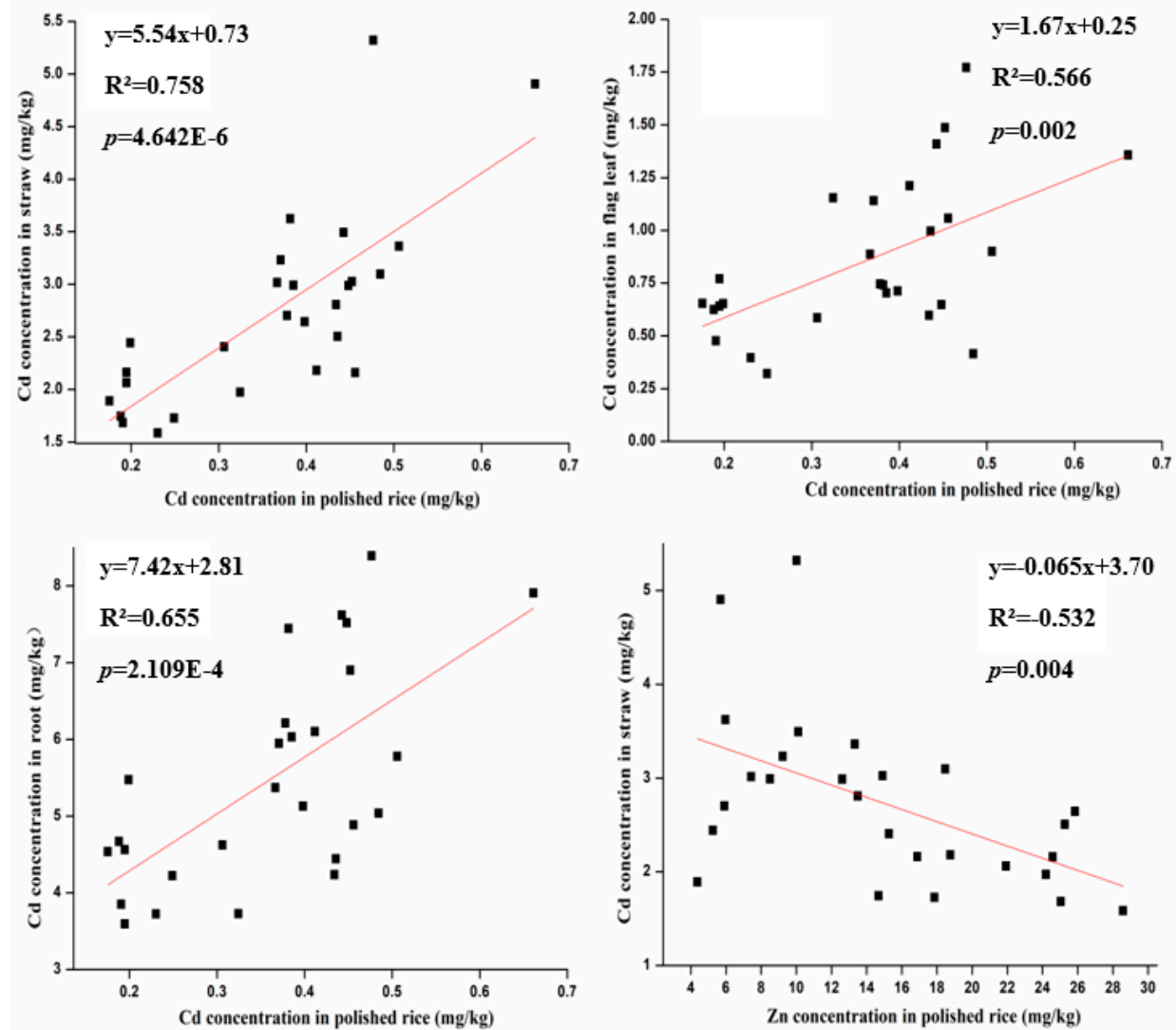

Figure 5. Linear correlations between $\mathrm{Cd}$, Zn concentration in polished rice and Cd concentration in different parts of the plant.

\subsection{Genotypic Classification of Late Rice Cultivars Based on Cd Accumulation}

Genotypic classification of cultivars based on the $\mathrm{Cd}$ concentration was analyzed by the hierarchical cluster analysis with Euclidean distance using the Ward's method. The hierarchical cluster analysis was used to predict the cultivars with same accumulation characteristics on the basis of $\mathrm{Cd}$ accumulation in the polished rice (Figure 6).

The concentration of $\mathrm{Cd}$ in polished rice was classified into five groups at five Euclidean distances. The cultivars LR-18, LR-26, LR-15, LR-12, LR-25, LR-17, LR-24 and LR-1 fell in the same group and were considered as low accumulators since their grain $\mathrm{Cd}$ concentration was below the permissible limit $\left(0.2 \mathrm{mg} \mathrm{kg}^{-1}\right)$.

The variation in the metal uptake in different cultivars maybe due to different acquisition capabilities of root and varies in ability to uptake and transfer [45], translocation and plant metabolic characteristics [46]. Nan [47] reported that various environmental factors could affect the bioavailability and metal accumulation in plants. Some studies reported that soil $\mathrm{pH}$, cation exchange capacity (CEC), organic matter $(\mathrm{OM})$ and soil texture could be important for the metal bioavailability and uptake by the crop plants $[48,49]$. Thus, further studies are needed to investigate the effects of soil physic-chemical properties on metal accumulation in plants, especially in the edible parts. 


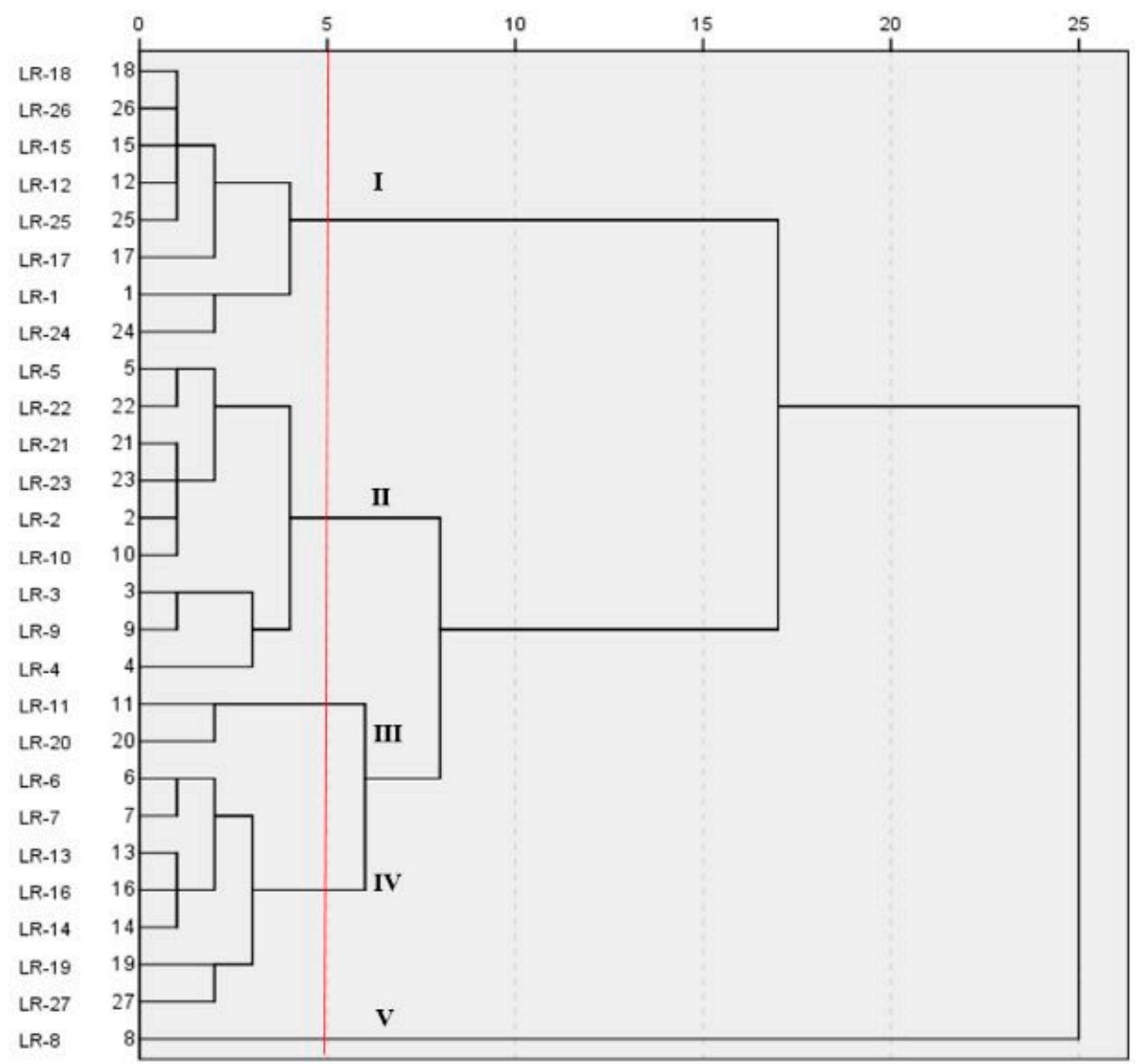

Figure 6. Cluster pattern of late rice cultivars on the basis of $\mathrm{Cd}$ accumulation in polished rice.

\subsection{Selection Criteria for the Safe Cultivar}

Genotypic difference in grain $\mathrm{Cd}$ accumulation provides the possibility to screen safe cultivars for production on the contaminated soils. Several factors need to be considered in screening safe or low accumulator (grains) cultivars [20], including low $\mathrm{Cd}$ accumulation in edible parts, TF lower than 1 and no $\mathrm{Cd}$ toxicity. For the present research we used the following standards for screening of low accumulator or safe cultivars: (i) polished rice $\mathrm{Cd}$ concentration $<0.2 \mathrm{mg} \mathrm{kg}^{-1}$, (ii) high Cd accumulation in straw, (iii) TF $<1.0$ and (iv) high grain yield and essential nutrients. After the 1st screening of cultivars, we divided the cultivars into three groups as high, medium and low $\mathrm{Cd}$ accumulator on the basis of the above standards as described in the heat map (Figure 7).

In the second year, the screening results showed that the cultivars LR-15 and LR-17 fulfilled the selection criteria with higher grain yield and mineral nutrient concentration and low $\mathrm{Cd}$ accumulation in polished rice (Table 2). 
Table 2. Grain Cd concentration, grain yield and mineral nutrient concentration in polished rice of cultivars in the 2nd year experiment. Data are means of three replicates; followed by different letters indicate significant difference $p<0.05$. MID and HIGH represent medium and high Cd accumulation cultivars in the first-year experiment.

\begin{tabular}{|c|c|c|c|c|c|c|c|c|c|}
\hline Type & Cultivars & Cd Conc. $\left(\mathrm{mg} \mathrm{kg}^{-1}\right)$ & Grains Yield ( $\left.\mathrm{kg} \mathrm{Mu}^{-1}\right)$ & $\mathrm{Cu}\left(\mathrm{mg} \mathrm{kg}^{-1}\right)$ & $\mathrm{Fe}\left(\mathrm{mg} \mathrm{kg} \mathrm{kg}^{-1}\right)$ & $\mathrm{Mn}\left(\mathrm{mg} \mathrm{kg}{ }^{-1}\right)$ & $\mathrm{Zn}\left(\mathrm{mg} \mathrm{kg} \mathbf{k g}^{-1}\right)$ & Protein $\%$ & Phytic Acid \\
\hline \multirow{3}{*}{ LOW } & LR-12 & $0.20 \pm 0.00 \mathrm{~d}$ & $486.36 \pm 0.94 b$ & $2.32 \pm 0.08 \mathrm{e}$ & $12.5 \pm 1.71 \mathrm{~d}$ & $16.03 \pm 0.22$ ef & $18.73 \pm 0.23 \mathrm{~cd}$ & $9.42 \pm 0.07 c$ & $2.89 \pm 0.06 b$ \\
\hline & LR-15 & $0.17 \pm 0.00 \mathrm{~d}$ & $558.67 \pm 1.11 \mathrm{a}$ & $2.93 \pm 0.06 b c$ & $14.29 \pm 0.24 \mathrm{~d}$ & $26.24 \pm 1.52 b c$ & $23.67 \pm 0.42 b$ & $10.17 \pm 0.08 b$ & $1.50 \pm 0.33 \mathrm{~cd}$ \\
\hline & LR-17 & $0.18 \pm 0.00 \mathrm{~d}$ & $395.02 \pm 1.04 \mathrm{~g}$ & $3.21 \pm 0.11 \mathrm{a}$ & $22.65 \pm 0.99 \mathrm{a}$ & $34.18 \pm 1.71 \mathrm{a}$ & $26.86 \pm 1.03 \mathrm{a}$ & $8.42 \pm 0.25 \mathrm{~d}$ & $1.64 \pm 0.17 \mathrm{~cd}$ \\
\hline \multirow{3}{*}{ MID } & LR-18 & $0.26 \pm 0.01 \mathrm{~cd}$ & $449.63 \pm 6.29 c$ & $2.63 \pm 0.04 \mathrm{~d}$ & $12.39 \pm 0.35 \mathrm{~d}$ & $15.24 \pm 0.08 \mathrm{ef}$ & $16.76 \pm 0.02 \mathrm{de}$ & $8.70 \pm 0.03 \mathrm{~d}$ & $1.31 \pm 0.11 \mathrm{~d}$ \\
\hline & LR-7 & $0.28 \pm 0.03 \mathrm{~cd}$ & $436.14 \pm 0.86 \mathrm{~d}$ & $2.27 \pm 0.03 \mathrm{e}$ & $17.60 \pm 0.42 c$ & $18.61 \pm 0.21 \mathrm{def}$ & $16.34 \pm 0.15 \mathrm{e}$ & $8.79 \pm 0.08 \mathrm{~d}$ & $1.26 \pm 0.25 \mathrm{~d}$ \\
\hline & LR-16 & $0.33 \pm 0.01 \mathrm{c}$ & $413.69 \pm 1.79 \mathrm{f}$ & $2.28 \pm 0.04 \mathrm{e}$ & $12.63 \pm 1.72 \mathrm{~d}$ & $13.33 \pm 0.18 \mathrm{f}$ & $17.41 \pm 0.41$ cde & $8.02 \pm 0.14 \mathrm{e}$ & $1.44 \pm 0.06 \mathrm{~cd}$ \\
\hline \multirow{3}{*}{ HIGH } & LR-19 & $0.54 \pm 0.05 b$ & $409.92 \pm 0.09 \mathrm{f}$ & $2.73 \pm 0.06 \mathrm{~cd}$ & $18.58 \pm 0.94 b c$ & $29.80 \pm 5.15 \mathrm{ab}$ & $19.14 \pm 1.4 \mathrm{c}$ & $10.01 \pm 0.07 b$ & $3.53 \pm 0.13 \mathrm{a}$ \\
\hline & LR3 & $0.56 \pm 0.05 b$ & $426.84 \pm 0.11 \mathrm{e}$ & $3.06 \pm 0.11 \mathrm{ab}$ & $20.98 \pm 1.29 \mathrm{ab}$ & $24.44 \pm 0.03 \mathrm{bcd}$ & $17.91 \pm 0.08$ cde & $10.66 \pm 0.03 a$ & $3.62 \pm 0.11 \mathrm{a}$ \\
\hline & LR-4 & $0.74 \pm 0.06 \mathrm{a}$ & $492.56 \pm 0.85 b$ & $2.82 \pm 0.05 \mathrm{~cd}$ & $22.70 \pm 0.87 \mathrm{a}$ & $21.26 \pm 1.43 \mathrm{cde}$ & $17.39 \pm 0.7$ cde & $7.75 \pm 0.15 \mathrm{e}$ & $1.94 \pm 0.06 \mathrm{c}$ \\
\hline
\end{tabular}




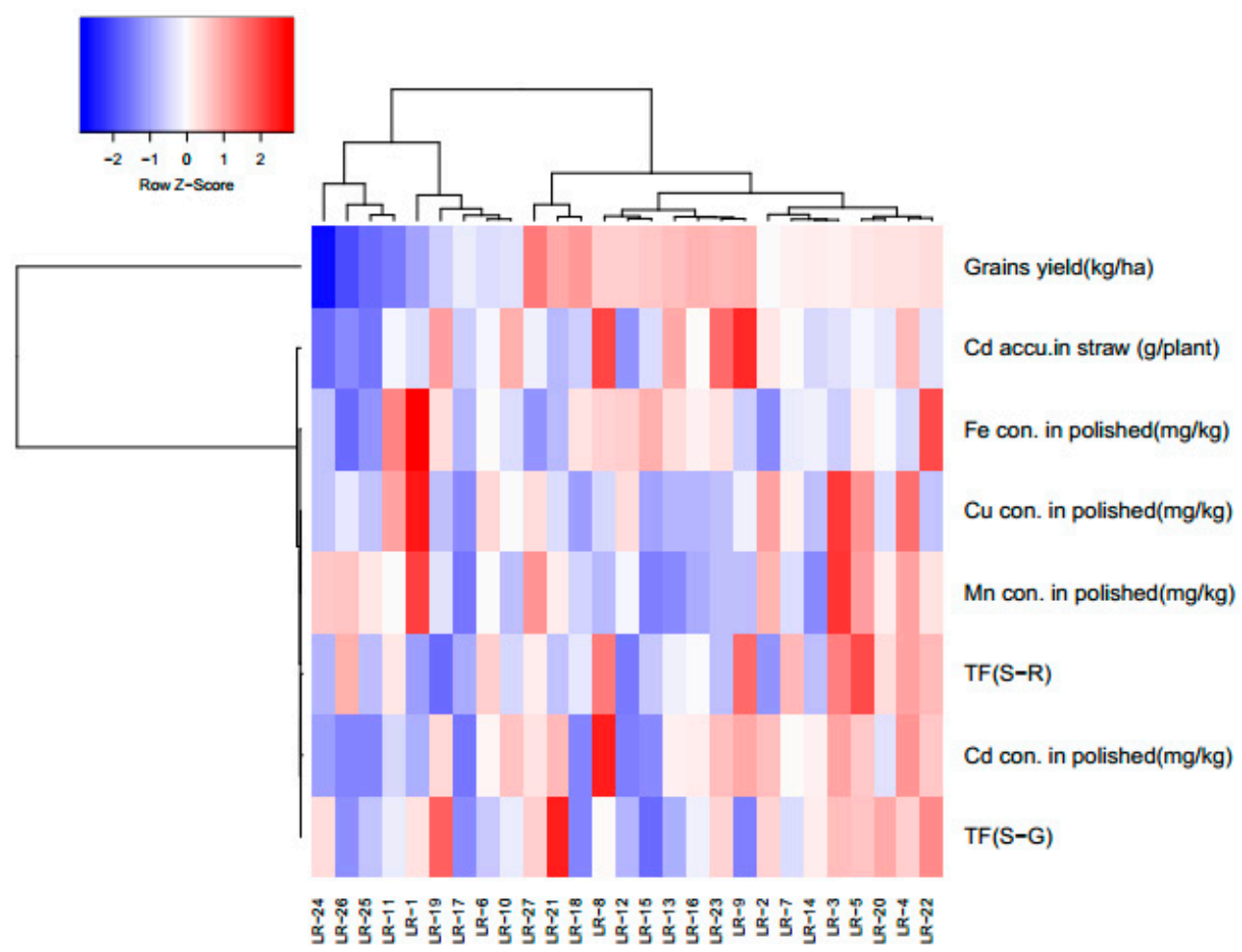

Figure 7. Criteria for the selection of safe production of late rice cultivars.

\subsection{Health Risk Assessment Associated with Cd Ingestion}

Cadmium is a hazardous metal for human health as its toxicity can impair susceptible organs (kidneys). Therefore, it is necessary to minimize human exposure and decrease potential health risks associated with $\mathrm{Cd}$ ingestion through food. Estimated daily intake (EDI) of Cd ingestion was calculated on the basis of daily consumption $0.25-0.4 \mathrm{~kg}$ (Figure 8 ) and then divided by $70 \mathrm{~kg}$ (an average human body weight) $[50,51]$. The maximum permissible limit of $\mathrm{Cd}$ intake set by Joint FAO/WHO Expert Committee on Food Additives (JECFA) [52] is $0.25 \mathrm{\mu g} \mathrm{kg}^{-1}$, so we calculated the daily dietary intake of polished rice on the basis of the maximum threshold limit (Figure 8).

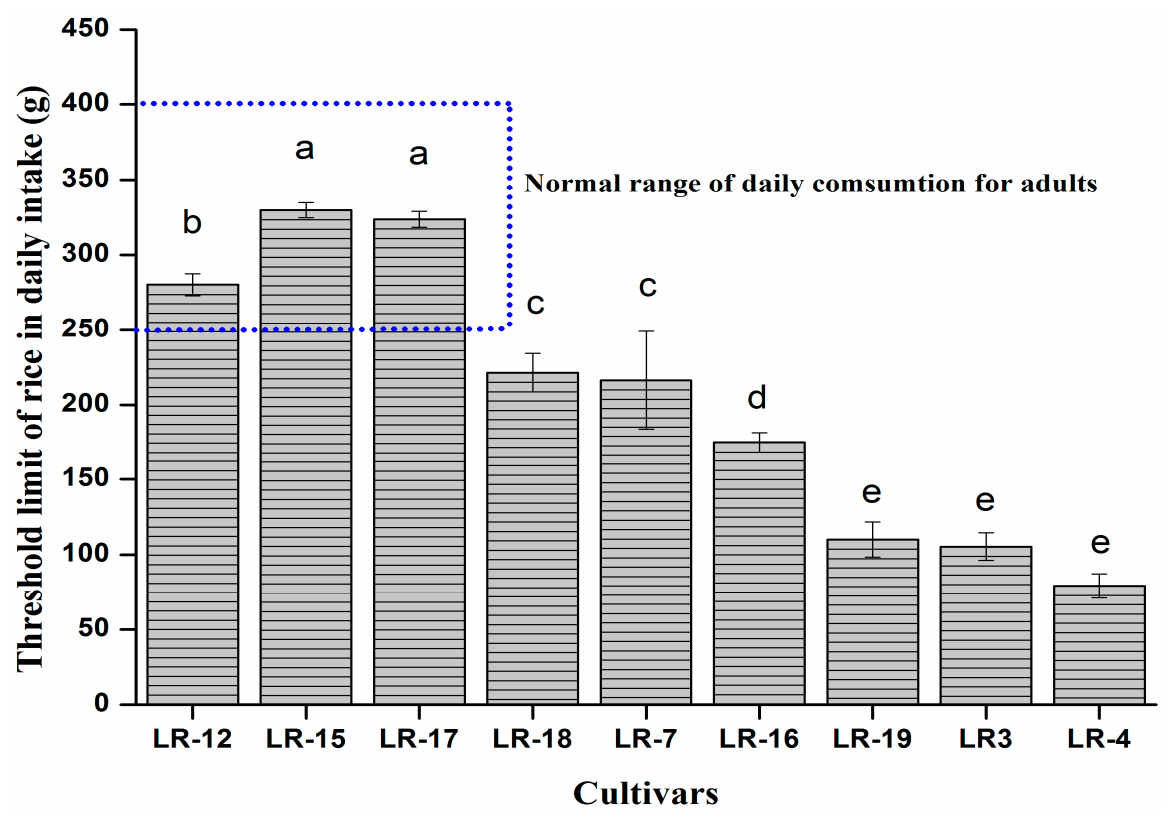

Figure 8. Daily dietary threshold limit of late rice grain on the basis of $\mathrm{Cd}$ concentration in polished rice. 
We selected nine cultivars for the 2nd year experiment to verify the 1st year's results. On the basis of Cd accumulation in polished rice only three cultivars (LR-12, LR-15 and LR-17) were in the normal range of daily intake. While LR-15 and LR-17 polished rice consumption on behalf of Cd concentration were less than the provisional tolerable daily intake (PTDI) recommended by the JECFA [52], which are found safe for daily dietary consumption of polished rice up to 330 and $325 \mathrm{~g}$, respectively. Meanwhile, the remaining cultivars were below the normal range of daily intake by the Chinese people. Among all the cultivars, the LR-4 showed the lowest quantity $(75 \mathrm{~g})$ for Cd safe daily dietary intake.

\subsection{Phytic Acid, Protein Content and Mineral Nutrient Concentration in Polished Rice}

There was significant differences in nutrient concentration among the prescreened cultivars and selected for the second year experiment (Table 2). Iron (Fe) concentration in polished rice grains varied from 22.65 (LR-4) to $12.39 \mathrm{mg} \mathrm{kg}^{-1}$ (LR-18), while LR-17 had the highest concentration of manganese $(\mathrm{Mn})$ and zinc $\left(\mathrm{Zn} ; 34.18\right.$ and $26.86 \mathrm{mg} \mathrm{kg}^{-1}$, respectively). It was noteworthy that LR-16 and LR-7 showed the lowest Mn and Zn concentration in grains (13.33 and $16.34 \mathrm{mg} \mathrm{kg}^{-1}$, respectively). $\mathrm{Cu}$ concentration in polished rice ranged from 3.21 (LR-17) to $2.27 \mathrm{mg} \mathrm{kg}^{-1}$ (LR-7) among the cultivars. Growth and development of plants depended upon the availability of macro as well as micronutrients $[53,54]$. So, various interactions occurred to nutrients during the uptake and accumulation processes [55]. Phloem sap is considered the nearest source of mineral elements for the developing grains. The variations between trace metals and mineral elements demonstrate the selectivity of grains for mineral elements, and thus, there is a significant difference in grain mineral nutrient concentrations among the rice cultivars.

Phytic acid and protein contents varied in the high, medium, and low accumulator cultivar (Table 2). Phytic acid in polished rice grains ranged from 3.62 in LR-3 to $1.26 \mathrm{mg} \mathrm{g}^{-1}$ in LR-7. The results from the present study showed that cultivars differed in phytic acid contents, which may affect $\mathrm{Cd}$ concentration in polished rice. Low phytic acid contents in cereals are considered important for the bioaccessibility of mineral nutrients. Egli [56] stated that the lesser phytate concentration in grains might lead to the elevated mineral contents ( $\mathrm{Zn}$ and Fe). Some other studies also revealed that low concentration of phytate might increase the assimilation of $\mathrm{Zn}$ and Fe [57,58].

\section{Conclusion}

In this study, we conducted two-year experiments to screen low $\mathrm{Cd}$ accumulator late rice, by evaluating 27 cultivars in the first year proceeded by 9 cultivars as low, medium and high accumulators to verify in the 2nd year experiment. Five genotypes (LR-12, LR-17, LR-15, LR-18, LR-25 and LR-26) were identified as a low $\mathrm{Cd}$ accumulator with high mineral nutrient concentration and among them LR-12, LR-15 and LR-17 were evaluated as safe cultivars and cultivated again in the 2nd year for verification. Based on the verification results the two cultivars, i.e., LR-15 and LR-17, were considered suitable for cultivation on slightly or moderately $\mathrm{Cd}$ contaminated soil owing to their low $\mathrm{Cd}$ accumulation in grain, minimal health risk and relatively high nutrient concentrations in polished rice. These two cultivars also fulfilled the threshold limit for human consumption based on Cd dietary intake in the respective area. Screening of low $\mathrm{Cd}$ accumulator cultivars is a feasible and appropriate approach for safe production of rice as conventional breeding methods for Cd tolerance cultivars is often time consuming and costly. However, further research is needed to understand the metal uptake and accumulation mechanisms, with different soil types, interactions between $\mathrm{Cd}$ and mineral nutrients for the safe production of nutritive crops.

Supplementary Materials: The following are available online at http://www.mdpi.com/1660-4601/17/10/3632/s1, Table S1. Cultivars information tested for the Cd uptake, accumulation and health risk assessment.

Author Contributions: Data curation, M.L.; Formal analysis, W.T. and Z.H.; Supervision, X.Y.; Writing-original draft, B.H.; Writing-review \& editing, Q.L. and Y.H. All authors have read and agreed to the published version of the manuscript. 
Funding: This research work was supported from Zhejiang Provincial Science and Technology Bureau (\#2018C02029, Shanghai Agricultural Commission (\#2019-02-08-00-08-F01134), Ministry of Science and Technology of China (\#2016YFD0800805), and the fundamental Research Funds for the Central Universities of China.

Conflicts of Interest: The authors declare no conflict of interest.

\section{References}

1. Wang, F.Y.; Shi, Z.Y.; Xu, X.F.; Wang, X.G.; Li, Y.J. Contribution of AM inoculation and cattle manure to lead and cadmium phytoremediation by tobacco plants. Environ. Sci. Process. Impacts 2013, 15, 794-801. [CrossRef]

2. Hamid, Y.; Tang, L.; Muhammad, I.S.; Cao, X.R.; Hussain, B.; Muhammad, Z.A.; Muhammad, U.; He, Z.L.; Yang, X.E. An explanation of soil amendments to reduce cadmium phytoavailability and transfer to food chain. Sci. Total Environ. 2019, 660, 80-96. [CrossRef]

3. Hussain, B.; Lin, Q.; Hamid, Y.; Sanaullah, M.; Di, L.; Hashmi, M.; Yang, X.E. Foliage application of selenium and silicon nanoparticles alleviates $\mathrm{Cd}$ and $\mathrm{Pb}$ toxicity in rice (Oryza sativa L.). Sci. Total Environ. 2020, 712, 136497. [CrossRef] [PubMed]

4. Krystofova, O.; Zitka, O.; Krizkova, S.; Hynek, D.; Shestivska, V.; Adam, V.; Hubalek, J.; Mackova, M.; Macek, T.; Zehnalek, J.; et al. Accumulation of cadmium by transgenic tobacco plants (Nicotiana tabacum L.) carrying yeast metallothione in gene revealed by electrochemistry. Int. J. Electrochem. Sci. 2012, 8, 886-907.

5. Xie, L.H.; Tang, S.Q.; Wei, X.J.; Shao, G.N.; Jiao, G.A.; Sheng, Z.H. The cadmium and lead content of the grain produced by leading Chinese rice cultivars. Food Chem. 2017, 217, 217-224. [CrossRef] [PubMed]

6. Cao, X.R.; Wang, X.Z.; Tong, W.B.; Gurajala, H.M.; Lu, M.; Hamid, Y.; Feng, Y.; He, Z.L.; Yang, X.E. Distribution, availability and translocation of heavy metals in soil oilseed rape (Brassica napus L.) system related to soil properties. Environ. Pollut. 2019, 252,733-741. [CrossRef]

7. Vatanpour, N.; Feizy, J.; Talouki, H.H.; Es'haghi, Z.; Scesi, L.; Malvandi, A.M. The high levels of heavy metal accumulation in cultivated rice from the Tajan river basin: Health and ecologic al risk assessment. Chemosphere 2020, 245, 125639. [CrossRef]

8. Ying, H. The Exploring of Heavy Metal Pollution Source Apportionmentin Various Scale of Agriculture Soils. Ph.D. Thesis, Zhejiang University, Hangzhou, China, 2018; p. 147.

9. Hamid, Y.; Tang, L.; Muhammad, Y.; Bilal, H.; Afsheen, Z.; Muhammad, Z.A.; He, Z.L.; Yang, X.E. Comparative efficacy of organic and inorganic amendments for cadmium and lead immobilization in contaminated soil under rice wheat cropping system. Chemosphere 2019, 214, 259-268. [CrossRef] [PubMed]

10. Zhu, Q.; Huang, D.; Liu, S.; Luo, Z.; Rao, Z.; Cao, X.; Ren, X. Accumulation and subcellular distribution of cadmium in ramie (Boehmerianivea L. Gaud.) planted one elevated soil cadmium contents. Plant Soil Environ. 2013, 59, 57-61.

11. Hamid, Y.; Tang, L.; Lu, M.; Hussain, B.; Zehra, A.; Bilal, K.M.; He, Z.L.; Kumar, G.H.; Yang, X.E. Assessing the immobilization efficiency of organic and inorganic amendments for cadmium phytoavailability to wheat. J. Soils Sediments 2019, 19, 3708-3717. [CrossRef]

12. Sebastian, A.; Prasad, M.N.V. Cadmium minimization in rice. A review. Agron. Sustain. Dev. 2014, 34, 155-173. [CrossRef]

13. Hamid, Y.; Tang, L.; Wang, X.Z.; Bilal, H.; Muhammad, Y.; Muhammad, Z.A.; Yang, X.E. Immobilization of cadmium and lead in contaminated paddy field using inorganic and organic additives. Sci. Rep. 2018, 8, 17839. [CrossRef]

14. Hamid, Y.; Tang, L.; Hussain, B.; Usman, M.; Lin, Q.; Rashid, M.S.; He, Z.L.; Yang, X.E. Organic soil additives for the remediation of cadmium contaminated soils and their impact on the soil-plant system: A review. Sci. Total Environ. 2020, 707, 136121. [CrossRef] [PubMed]

15. Zhao, X.L.; Li, Y.E. Variation of cadmium tolerance and accumulation in different tobacco cultivars. J. Southwest Univ. 2007, 3, 110-114. (In Chinese)

16. Wang, X.; Shi, Y.; Chen, X.; Huang, B. Screening of Cd-safe genotypes of Chinese cabbage in field condition and $\mathrm{Cd}$ accumulation in relation to organic acids in two typical genotypes under long-term Cd stress. Environ. Sci. Pollut. Res. 2015, 22, 16590-16599. [CrossRef]

17. Xu, W.D.; Lu, G.N.; Dang, Z.; Liao, C.J.; Chen, Q.P.; Yi, X.Y. Uptake and distribution of Cd in sweet maize grown on contaminated soils: Afield-scale study. Bioinorg. Chem. Appl. 2013, 2013, 959764. [CrossRef] 
18. Page, V.; Feller, U. Selective transport of zinc, manganese, nickel, cobalt and cadmium in the root system and transfer to the leaves in young wheat plants. Ann. Bot.-Lond. 2005, 96, 425-434. [CrossRef]

19. Alexander, P.D.; Alloway, B.J.; Dourado, A.M. Genotypic variations in the accumulation of $\mathrm{Cd}, \mathrm{Cu}, \mathrm{Pb}$ and Zn exhibited by six commonly grown vegetables. Environ. Pollut. 2006, 144, 736-745. [CrossRef]

20. Liu, C.S.; Sun, B.Y.; Kan, S.H.; Zhang, Y.Z.; Deng, S.H.; Yang, G. Copper toxicity and accumulation in potted seedlings of three apple rootstock species: Implications for safe fruit production on copper-polluted soils. J. Plant Nutr. 2010, 34, 1268-1277. [CrossRef]

21. Tang, L.; Hamid, Y.; Zehra, A.; Sahito, Z.A.; He, Z.L.; Khan, M.B.; Feng, Y.; Yang, X.E. Mechanisms of water regime effects on uptake of cadmium and nitrate by two ecotypes of water spinach (Ipomoea aquatica Forsk.) in contaminated soil. Chemosphere 2020, 246, 125798. [CrossRef]

22. Arao, T.; Ae, N.; Sugiyama, M.; Takahashi, M. Genotypic differences in cadmium uptake and distribution in soybeans. Plant Soil. 2003, 251, 247-253. [CrossRef]

23. Williams, P.N.; Lei, M.; Sun, G.; Huang, Q.; Lu, Y.; Deacon, C. Occurrence and partitioning of cadmium, arsenic and lead in mine impacted paddy rice: Hunan, China. Environ. Sci. Technol. 2009, 43, 637-642. [CrossRef] [PubMed]

24. Analysis of Agricultural Meteorological Conditions of Quhou in 2019. Available online: http://nyncj.qz.gov. cn/art/2019/1/8/art_1594264_33925418.html (accessed on 19 May 2020).

25. Li, H.S. Principle and Technology of Plant Physiological and Biochemical Experiment; Higher Education Press: Beijing, China, 2000. (In Chinese)

26. Bao, S.D. Soil Agricultural Chemistry Analysis Method, 3rd ed.; China Agriculture Press: Beijing, China, 2008. (In Chinese)

27. Dai, F.; Wang, J.; Zhang, S.; Xu, Z.; Zhang, G. Genotypic and environmental variation in phytic acid content and its relation to protein content and malt quality in barley. Food Chem. 2007, 105, 606-611. [CrossRef]

28. Bai, Y.C.; Zuo, W.G.; Zhao, H.T.; Mei, L.J.; Gu, C.H.; Guan, Y.X.; Wang, X.K.; Gu, M.J.; Zang, C.Y.; Shan, Y.H. Distribution of heavy metals in maize and mudflat saline soil amended by sewage sludge. J. Soils Sediments 2017, 17, 1565-1578. [CrossRef]

29. Wodle, T.B.; Weldemariam, S.G.; Tian, S.K. Maize cultivars relieve health risks of Cd-Polluted Soils: In vitro Cd bioaccessibility and bioavailability. Sci. Total Environ. 2020, 703, 134852.

30. Reynolds, M.; Foulkes, J.; Furbank, R.; Griffiths, S.; King, J.; Murchie, E.; Parry, M.; Slafer, G. Achieving yield gains in wheat. Plant Cell Environ. 2012, 35, 1799-1823. [CrossRef]

31. Abacar, J.D.; Zhao, M.L.; Xin, C.Z.; Cheng, Q.D.; She, T.; Zheng, H.L.; Shao, H.W.; Yan, F.D. Variation in yield and physicochemical quality traits among mutants of Japonica rice cultivar Wuyujing 3. Rice Sci. 2016, 23, 33-41. [CrossRef]

32. Koutroubas, S.D.; Mazzini, F.; Pons, B.; Ntanos, D.A. Grain quality variation and relationships with morpho-physiological traits in rice (Oryza sativa L.) genetic resources in Europe. Field Crops Res. 2004, 86, 115-130. [CrossRef]

33. Lu, M.; Cao, X.R.; Pan, J.Q.; Li, T.Q.; Khan, M.B.; Gurajala, H.K.; He, Z.L.; Yang, X.E. Identification of wheat (Triticum aestivum L.) genotypes for food safety on two different cadmium contaminated soils. Environ. Sci. Pollut. Res. 2019, 27, 7943-7956. [CrossRef]

34. Ye, X.; Ma, Y.; Sun, B. Influence of soil type and genotype on Cd bioavailability and uptake by rice and implications for food safety. J. Environ. Sci. 2012, 24, 1647-1654. [CrossRef]

35. Yan, Y.F.; Choi, D.H.; Kim, D.S.; Lee, B.W. Genotypic variation of cadmium accumulation and distribution in rice. J. Crop Sci. Biotechnol. 2010, 13, 69-73. [CrossRef]

36. Davies., B.E.; Alloway, B.J. Heavy Metals in Soils; Blackie Academic: London, UK, 1995; pp. 206-223.

37. Stoltz, E.; Greger, M. Accumulation properties of $\mathrm{As}, \mathrm{Cd}, \mathrm{Cu}, \mathrm{Pb}$ and $\mathrm{Zn}$ by four wetland plant species growing on submerged mine tailings. Environ. Exp. Bot. 2002, 47, 271-280. [CrossRef]

38. Zeng, F.R.; Mao, Y.; Cheng, W.D.; Wu, F.B.; Zhang, G.P. Genotypic and environmental variation in chromium, cadmium and lead concentrations in rice. Environ. Pollut. 2008, 153, 309-314. [CrossRef] [PubMed]

39. Liu, W.; Liang, L.; Zhang, X.; Zhou, Q. Cultivar variations in cadmium and lead accumulation and distribution among 30 wheat (Triticum aestivum L.) cultivars. Environ. Sci. Pollut. Res. 2015, 22, 8432-8441. [CrossRef] [PubMed]

40. Deng, H.; Ye, Z.H.; Wong, M.H. Accumulation of lead, zinc, copper and cadmium by 12 wetland plant species thriving in metal-contaminated sites in China. Environ. Pollut. 2004, 132, 29-40. [CrossRef] [PubMed] 
41. Yang, J.X.; Ma, Z.L.; Ye, Z.H.; Guo, X.Y.; Qiu, R.L. Heavy metal (Pb, Zn) uptake and chemical changes in rhizosphere soils of four wetland plants with different radial oxygen loss. J. Environ. Sci. 2010, 22, 696-702. [CrossRef]

42. Wu, C.Y.; Feng, Y.; Shohag, M.J.I.; Lu, L.L.; Wei, Y.Y.; Gao, C.; Yang, X.E. Characterization of 68 Zn uptake, translocation, and accumulation into developing grains and young leaves of high Zn-density rice genotype. J. Zhejiang Univ. Sci. B (Biomed. Biotechnol.) 2011, 12, 408-418. [CrossRef]

43. Tanaka, K.; Fujimaki, S.; Fujiwara, T.; Yoneyama, T.; Hayashi, H. Quantitative estimation of the contribution of the phloem in cadmium transport to grains in rice plants (Oryza sativa L.). Soil Sci. Plant Nutr. 2007, 53, 72-77. [CrossRef]

44. Yoon, J.K.; Cao, X.D.; Zhou, Q.X.; Ma, L.Q. Accumulation of $\mathrm{Pb}, \mathrm{Cu}$, and $\mathrm{Zn}$ in native plants growing on a contaminated Florida site. Sci. Total Environ. 2006, 368, 456-464. [CrossRef]

45. Zhang, H.Z.; Guo, Q.J.; Yang, J.X.; Chen, T.B.; Chen, H.; Shen, J.X.; Zhu, G.X.; Wang, X.; Sun, Y.C. Cadmium and mineral nutrients accumulation in various genotypes of Castor under cadmium stress. Ecol. Environ. Sci. 2015, 24, 323-328.

46. Liu, Y.; Zhang, C.; Zhao, Y.; Sun, S.; Liu, Z. Effects of growing seasons and genotypes on the accumulation of cadmium and mineral nutrients in rice grown in cadmium contaminated soil. Sci. Total Environ. 2017, 579, 1282-1288. [CrossRef] [PubMed]

47. Nan, Z.R.; Zhao, C.Y.; Li, J.J.; Chen, F.H.; Sun, W. Relations between soil properties and selected heavy metal concentrations in spring wheat (Triticum a estivum L.) grown in contaminated soils. Water Air Soil Pollut. 2002, 133, 205-213. [CrossRef]

48. Dala-Paula, B.M.; Custodio, F.B.; Knupp, E.A.N.; Palmieri, H.E.L.; Silva, J.B.B.; Gloria, M.B.A. Cadmium, copper and lead levels in different cultivars of lettuce and soil from urban agriculture. Environ. Pollut. 2018, 242, 383-389. [CrossRef] [PubMed]

49. Li, N.; Kang, Y.; Pan, W.; Zeng, L.; Zhang, Q.; Luo, J. Concentration and transportation of heavy metals in vegetables and risk assessment of human exposure to bioaccessible heavy metals in soil near a waste-incinerator site, South China. Sci. Total Environ. 2015, 521, 144-151. [CrossRef] [PubMed]

50. Zhai, F.Y.; He, Y.N.; Ma, G.S.; Li, Y.; Wang, Z.; Hu, Y.; Zhao, Y.; Cui, Y.; Li, Y.; Yang, Y. Study on the current status and trend of food consumption among Chinese population. Zhong Hua Liu Xing Bing Xue Zazhi 2015, 26, 485-488.

51. Zheng, N.; Wang, X.Q.; Zhang, D.; Zheng, Z.; Zhang, S.Z. Population health risk due to dietary intake of heavy metals in the industrial area of Hulu dao city, China. Sci. Total Environ. 2007, 387, 96-104. [CrossRef]

52. JECFA. Proceedings of the Joint FAO/WHO Expert Committee on Food Additives, Seventy-Third Meeting, Geneva, Switzerland, 8-17 June 2010; p. 2.

53. Sarwar, N.; Saifullah, M.S.S.; Zia, M.H.; Naeem, A.; Bibi, S.; Farid, G. Role of mineral nutrition in minimizing cadmium accumulation by plants. J. Sci. Food Agric. 2010, 90, 925-937. [CrossRef]

54. Shahid, M.; Shukla, A.K.; Bhattacharyya, P.; Tripathi, R.; Mohanty, S.; Kumar, A.; LaI, B.; Gautam, P.; Raja, R.; Panda, B.B.; et al. Micronutrients ( $\mathrm{Fe}, \mathrm{Mn}, \mathrm{Zn}$ and $\mathrm{Cu}$ ) balance under long-term application of fertilizer and manure in a tropical rice-rice system. J. Soils Sediments 2016, 16, 737-747. [CrossRef]

55. Pinto, E.; Ferreira, I.M. Cation transporters/channels in plants: Tools for nutrient biofortification. J. Plant Physiol. 2015, 179, 64-82. [CrossRef]

56. Egli, I.; Davidsson, L.; Zeder, C.; Walczyk, T.; Hurrell, R. Dephytinization of a complementary food based on wheat and soy increases zinc, but not copper, apparent absorption in adults. J. Nutr. 2014, 134, 1077-1081. [CrossRef]

57. Hurrell, R.F.; Reddy, M.B.; Juillerat, M.A.; Cook, J.D. Degradation of phytic acid in cereal porridges improves iron absorption by human subjects. Am. J. Clin. Nutr. 2003, 77, 1213-1219. [CrossRef] [PubMed]

58. Stmopen. Phytic acid content in different parts of grain and its correlation with rice quality traits. Adv. J. Food Sci. Technol. 2013, 2, 328-334.

(C) 2020 by the authors. Licensee MDPI, Basel, Switzerland. This article is an open access article distributed under the terms and conditions of the Creative Commons Attribution (CC BY) license (http://creativecommons.org/licenses/by/4.0/). 